J. Dairy Sci. 95:2935-2945

http://dx.doi.org/10.3168/jds.2011-4442

(C) American Dairy Science Association ${ }^{\circledR}, 2012$.

\title{
Selection of suitable reference genes for quantitative gene expression studies in milk somatic cells of lactating cows (Bos indicus)
}

\author{
N. Varshney, ${ }^{\star}$ A. K. Mohanty, ${ }^{\star 1}$ S. Kumar, ${ }^{\star}$ J. K. Kaushik, ${ }^{\star}$ A. K. Dang, ${ }^{\star}$ M. Mukesh, † B. P. Mishra, $†$ R. Kataria, $\dagger$ \\ S. P. Kimothi, ${ }^{\star}$ T. K. Mukhopadhyay, $¥$ D. Malakar, ${ }^{\star}$ B. S. Prakash, ${ }^{\star}$ S. Grover, ${ }^{\star}$ and V. K. Batish ${ }^{\star}$ \\ *National Dairy Research Institute, Karnal 132001, India \\ †National Bureau of Animal Genetic Resources, 132001 Karnal, India \\ ¥National Centre for Human Genome Studies and Research, Punjab University, 147002 Chandigarh, India
}

\section{ABSTRACT}

We assessed the suitability of 9 internal control genes (ICG) in milk somatic cells of lactating cows to find suitable reference genes for use in quantitative PCR (qPCR). Eighteen multiparous lactating Sahiwal cows were used, 6 in each of 3 lactation stages: early (25 $\pm 5 \mathrm{~d}$ in milk), mid $(160 \pm 15 \mathrm{~d}$ in milk), and late $(275 \pm 25 \mathrm{~d}$ in milk) lactation. Nine candidate reference genes [glyceraldehyde 3-phosphate dehydrogenase $(G A P D H)$, protein phosphatase 1 regulatory subunit 11 (PPP1R11), $\beta$-actin (ACTB), $\beta-2$ microglobulin $(B 2 M)$, 40S ribosomal protein S15a (RPS15A), ubiquitously expressed transcript (UXT), mitochondrial GTPase 1 (MTG1), 18S rRNA (RN18S1), and ubiquitin $(U B C)]$ were evaluated. Three genes, $\beta$-casein (CSN2), lactoferrin $(L T F)$, and cathelicidin $(C A M P)$ were chosen as target genes. Very high amplification was observed in 7 ICG and very low level amplification was observed in 2 ICG (UXT and MTG1). Thus, UXT and MTG1 were excluded from further analysis. The qPCR data were analyzed by 2 software packages, geNorm and NormFinder, to determine suitable reference genes, based on their stability and expression. Overall, PPP1R11, ACTB, UBC, and GAPDH were stably expressed among all candidate reference genes. Therefore, these genes could be used as ICG for normalization of qPCR data in milk somatic cells through lactation.

Key words: housekeeping gene, internal control, milk somatic cell, cow

\section{INTRODUCTION}

Milk somatic cells are present in milk throughout lactation. They consist of leucocytes and epithelial cells

Received April 13, 2011.

Accepted January 16, 2012.

${ }^{1}$ Corresponding author: ashokmohanty1@gmail.com exfoliated from mammary epithelium. The proportion of different cell types varies in different species. In most species, the predominant cell type is leucocytes, including lymphocytes, PMNL, and macrophages. In cows and ewes, macrophages represent the predominant cell type (35-79\%) acting against the invasion of pathogens causing mastitis (Boutinaud and Jammes, 2002). The PMNL, which represent 5 to $25 \%$ of total cells, phagocytose and destroy invading pathogens. The mammary epithelial cells (MEC) in the cow, although low in number ( $\sim 2 \%$ of SCC), are one of the important constituents of milk somatic cells (Feng et al., 2007; Boutinaud et al., 2008). The somatic cell count in milk is used as a marker to determine mammary health and quality of milk (Pfaffl et al., 2003; De et al., 2011).

Interest is increasing in understanding the physiology of lactation in dairy animals, particularly to explore which genes control the composition of milk and how these genes are regulated. For gene expression studies involving the mammary gland, mammary tissue biopsies are normally used as the source material. However, mammary gland biopsy is an invasive and expensive procedure, making it difficult for use on a routine basis for gene expression studies. Milk somatic cells have been reported to reveal, with some limitations, the cellular dynamics of mammary gene expression during lactation (Boutinaud et al., 2002; Feng et al., 2007; Medrano et al., 2010). Therefore, various researchers have used milk somatic cells as an alternative source for gene expression studies (Pfaffl et al., 2003; Murrieta et al., 2006; Boutinaud et al., 2008).

Reverse transcription-quantitative PCR (RT-qPCR) is one of the most common techniques used to study the expression profile of genes in various organs and tissues, including the mammary gland (Bionaz and Loor, 2007). Use of qPCR requires normalization of data with respect to an internal control, often referred to as a reference gene or internal control gene (ICG; Jung et al., 2002). Use of a reference gene as control eliminates errors arising due to sample loss 
during handling, variation in the kinetics of the reverse transcriptase, and variation in the morphology or activity of the sample taken, such as composition of cell types, change in mRNA composition, and so on. The concept behind selection of a reference gene is that the expression of ICG should not be regulated or affected by response to experimental treatments or the physiological state under investigation (Vandesompele et al., 2002). Therefore, the choice of a suitable ICG is critical. Although housekeeping genes were initially believed to be consistently expressed and therefore good ICG, the expression of certain housekeeping genes does fluctuate under different pathophysiological conditions (Schmittgen et al., 2000; Tricarico et al., 2002). Therefore, the ICG should be selected carefully on a case-by-case basis to avoid possible inaccuracies stemming from the use of an unsuitable reference gene (Dheda et al., 2005; Yüzbaşioğlu et al., 2010). Furthermore, the expression of such reference genes should be comparable to that of the target gene; that is, it should be not be underexpressed or overexpressed (Silver et al., 2006).

The selection of ICG becomes especially difficult when the study involves a long-term trial or longitudinal experiments such as the lactation cycle in dairy animals. The dramatic surge in milk yield during the first week of lactation is associated with a large increase in mammary RNA due to high expression of lactationspecific genes (e.g., casein, $\alpha$-LA). This appears to be the cause of the dilution effect in qPCR analysis as previously reported (Bionaz and Loor, 2007). No ideal ICG has yet been validated in milk somatic cells of cows during different stages of lactation. A few research papers on gene expression studies using somatic cells have been published and almost all of them have used a single ICG in the study (Pfaffl et al., 2003; Murrieta et al., 2006; Boutinaud et al., 2008). Use of a single gene without any proper evaluation regarding its suitability as an ICG may lead to analytical errors.

The current study was designed to find a suitable ICG for gene expression study in milk somatic cells during lactation, and lactoferrin $(L T F)$, cathelicidin $(C A M P)$, and $\beta$-casein (CSN2) genes were taken as target genes. Hence, we determined the expression stability of 9 ICG: protein phosphatase 1 regulatory subunit 11 (PPP1R11), 40S ribosomal protein S15a (RPS15A), ubiquitously expressed transcript (UXT), mitrochondrial GTPase1 homolog (MTG1), glyceraldehyde 3-phosphate dehydrogenase (GAPDH), $\beta$-actin $(A C T B), \beta 2$ microglobulin $(B 2 M), 18 \mathrm{~S}$ rRNA $(R N 18 S 1)$, and ubiquitin (UBC) to establish their suitability as ICG for RT-qPCR study in milk somatic cells.

\section{MATERIALS AND METHODS}

\section{Animal Selection and Sampling}

Eighteen indigenous Sahiwal cows were selected based on their lactation period; that is, 6 animals each from early, mid, and late lactation. The animals for the study were taken from the dairy herd of National Dairy Research Institute (Karnal, India). The milk samples were collected from animals that were maintained under expert veterinary supervision. The animals were healthy without incidence of clinical or subclinical mastitis, which were routinely tested by SCC and California Mastitis Test. The early, mid, and late stages were defined according the accepted standard lactation length of $300 \mathrm{~d}$ in cattle and changes in milk yield (De et al. 2011). Early, mid, and late lactating animals represented samples from $25 \pm 5 \mathrm{~d}, 160 \pm 15 \mathrm{~d}$, and $275 \pm$ 25 d postpartum, respectively.

\section{Milk Somatic Cell Isolation and Viability Test}

Fresh milk (200-500 mL) was collected from the selected animals and immediately centrifuged at $600 \times g$ at $4^{\circ} \mathrm{C}$ in $250-\mathrm{mL}$ centrifuge bottles. The fat layer from the top was removed with a spatula and the milk was discarded. The pelleted somatic cells were washed 3 times by centrifugation with $1 \times \mathrm{PBS}(\mathrm{pH} 7.4)$ at $600 \times$ $g$ at $4^{\circ} \mathrm{C}$ in $15-\mathrm{mL}$ centrifuge tubes. Total milk somatic cells were counted in a Neubauer counting chamber (Bright Line, Laboroptik GmbH, Bad Homburg, Germany). Viability of the collected cells was assessed by the trypan blue dye exclusion method by mixing $10 \mu \mathrm{L}$ of resuspended cells in PBS with an equal volume of trypan blue dye and counting the unstained cells under inverted microscope. Cell count was adjusted to $6 \times 10^{8}$ cells for all the samples for isolation of RNA.

\section{RNA Extraction and cDNA Synthesis}

Isolation of RNA was done using TRIzol (Invitrogen, Life Technologies, Grand island, NY), according to the manufacturer's protocol, and RNA integrity was assessed in 1.5\% agarose gel electrophoresis (Supplemental file S1; available at http://www.journalofdairyscience.org/). To rule out contamination with genomic DNA in RNA preparations, isolated RNA was treated using the Ambion DNA-free kit (Invitrogen) according to the manufacturer's protocol. The purity of RNA was checked by UV spectrometer (Beckman DU640, Beckman Coulter Inc., Indianapolis, IN) with the ratio of the optical density at 260 and $280 \mathrm{~nm}$ being $>1.8$. One microgram of DNA-free RNA was used for first-strand 
synthesis for each sample, and cDNA was synthesized using the Taqman reverse transcription reagents kit (Applied Biosystems, Foster City, CA). Briefly, $4 \mu \mathrm{L}$ of $5.5 \mathrm{mM} \mathrm{MgCl} 2,4.4 \mu \mathrm{L}$ of $500 \mu M$ dNTP each, 1 $\mu \mathrm{L}$ of $0.5 \mu \mathrm{M}$ oligo dT primers, $0.4 \mu \mathrm{L}$ of $0.4 \mathrm{U} / \mu \mathrm{L}$ RNase inhibitor, $0.5 \mu \mathrm{L}$ of $1.25 \mathrm{U} / \mu \mathrm{L}$ of Multiscribe reverse transcriptase (Applied Biosystems), RNase-free water, and $1 \mu \mathrm{g}$ of RNA were mixed to prepare $20 \mu \mathrm{L}$ of cDNA mix. The reaction was performed in Master Cycler gradient (Bio-Rad, Hercules, CA) using the following temperature-time program: $25^{\circ} \mathrm{C}$ for $5 \mathrm{~min}, 48^{\circ} \mathrm{C}$ for $30 \mathrm{~min}$, and $95^{\circ} \mathrm{C}$ for $5 \mathrm{~min}$. A control reaction (no reverse transcriptase) was also carried out similarly for all the RNA samples to confirm the absence of genomic DNA contamination.

\section{Selection of Genes and Primer Design}

Candidate reference genes for the current study were selected based upon the literature: $A C T B, G A P D H$, and B2M (Pérez et al., 2008); RPS15A and UXT (Bionaz and Loor, 2007); PPP1R11 and MTG1 (Piantoni et al., 2008); RN18S1 (Gubern et al., 2009); and UBC (Pfaffl, 2004). Those genes are also the most commonly used reference genes in the study of mammary gland and other tissues. Along with the candidate ICG, CSN2, $L T F$, and $C A M P$ were used as target genes whose expression was expected to be variable through lactation. The $\beta$-casein gene CSN2 is the most abundant protein in milk and is synthesized and secreted by MEC (Tomasinsig et al., 2010). Lactoferrin is an iron-binding glycoprotein that has bacteriostatic and bactericidal activities and is synthesized by glandular epithelial cells and neutrophils (Pfaffl et al., 2003); expression of LTF is indicative of udder involution, mastitis, or transition to defense response. Cathelicidin is expressed in leucocytes (Zanetti, 2005) and its overexpression indicates mastitis, subclinical mastitis, or white blood cell invasion of the tissue. Collectively, the expression of these genes is a very good indicator of the physiological and diseased state of the MEC in the sample. Primers were designed using bovine gene sequence data in GenBank. The primer design software Primer 3 (Rozen and Skaletsky, 2000) was used for primer design, with amplicon sizes in the range of 100 to $250 \mathrm{bp}$. The primer sequences were aligned against a publicly available database using the Primer BLAST software of the National Center for Biotechnology Information (http://www.ncbi.nlm.nih. gov/tools/primer-blast/) to rule out the possibility of any nonspecific priming. Sequences of primers for the 9 selected candidate reference genes and 3 control target genes (i.e., CSN2, $L T F$, and CAMP) are shown in Table
1. Primer specificities were evaluated by running agarose gel electrophoresis of the amplified PCR products followed by sequencing (Supplemental file S5; available at http://www.journalofdairyscience.org/).

\section{Real-Time PCR}

After selecting optimum annealing temperatures (Table 1), we produced 6-point standard curves with 5 -fold dilution series in duplicate for each gene, together with the sample assays (Cikos et al., 2007; Pérez et al., 2008). For sample assay, the samples from each animal in a group of 6 were run in duplicate. For all samples, a final volume of $20 \mu \mathrm{L}$ of $\mathrm{qPCR}$ master mix was prepared by adding $10 \mu \mathrm{L}$ of $2 \times$ SYBR Green I Master Mix (Roche Diagnostics, Mannheim, Germany), $1 \mu \mathrm{L}$ each of $(0.5 \mu M)$ forward and reverse primers, $1 \mu \mathrm{L}$ of first-strand cDNA, and $7 \mu \mathrm{L}$ of PCRgrade water. The $\mathrm{qPCR}$ reactions were performed in LightCycler 480 instrument (Roche Diagnostics, Basel, Switzerland) and the quantity was determined using the standard curve using the instrument's software and the second-derivative maximum method. This method identifies the crossing point $(\mathbf{C p})$ where the sample's fluorescence curve turns sharply upward and is based on the fact that the fluorescence is increasing at an ever-increasing rate in the exponential part of the reaction. This turning point corresponds to the maximum of the second derivative of the amplification curve. The acceleration of the fluorescence signal slows as the reaction enters in the plateau. Therefore, the cycle in which the second derivative is at maximum should always be in middle of the log linear portion of the reaction. This method automatically corrects for background florescence by calculating the arithmetic mean of cycles 2 to 6 and subtracting this mean from the fluorescence values (LightCycler 480 catalog, Roche Diagnostics).

The program for the PCR reactions was as follows: $95^{\circ} \mathrm{C}$ for 5 min, 40 cycles of $95^{\circ} \mathrm{C}$ for $10 \mathrm{~s}$, annealing temperature (Table 1) for $10 \mathrm{~s}$, and $72^{\circ} \mathrm{C}$ for $15 \mathrm{~s}$. Melting curves (dissociation curves) for each gene were performed using the following temperature program: $95^{\circ} \mathrm{C}$ for $5 \mathrm{~s}, 65^{\circ} \mathrm{C}$ for $1 \mathrm{~min}$, and $97^{\circ} \mathrm{C}$ for continuous mode, as per the set default value of instrument. Real-time PCR efficiencies $(\mathbf{E})$ were calculated from the given slopes in LightCycler Software 1.5 (Roche Diagnostics). The corresponding real-time PCR efficiency (E) was calculated according to the equation $\mathrm{E}=10^{[-1 / \text { slope }]}$ (performed by the instrument). The maximal efficiency of PCR is $\mathrm{E}=$ 2 (slope of $>-3.6$ to $<-3.1$ ), where every PCR product is replicated in every cycle, and the minimum value is $\mathrm{E}$ $=1$, corresponding to no replication. 
Table 1. Selected candidate internal control genes used in the reverse transcription quantitative PCR assay indicating name, GenBank accession number, function, primer sequence, and annealing temperature (Ta) used for the expression study

\begin{tabular}{|c|c|c|c|c|c|}
\hline \multirow{3}{*}{$\frac{\text { Gene }^{1}}{\text { PPP1R11 }}$} & \multirow{3}{*}{$\begin{array}{l}\text { Accession no. } \\
\text { NM_001100295 }\end{array}$} & \multirow{3}{*}{$\begin{array}{l}\text { Function } \\
\text { Specific inhibitor of protein phosphatase-1 (PP1) } \\
\text { with a differential sensitivity toward the metal-independent } \\
\text { and metal-dependent forms of PP }\end{array}$} & \multicolumn{2}{|c|}{ Sequence $^{2}$} & \multirow{3}{*}{$\frac{\mathrm{Ta}\left({ }^{\circ} \mathrm{C}\right)}{60}$} \\
\hline & & & $\mathrm{F}$ & 5'-ACCATCAAACTTCGGAAACG-3' & \\
\hline & & & $\mathrm{R}$ & 5'-ССТССТСТTCCTCGTCATCA-3' & \\
\hline \multirow[t]{2}{*}{$A C T B$} & \multirow[t]{2}{*}{ NM_173979 } & Nonmuscle cytoskeletal actin involved in & $\mathrm{F}$ & 5'-CTCTTCCAGCCTTCCTTCCT-3' & \multirow[t]{2}{*}{63} \\
\hline & & cell motility, structure, and integrity & $\mathrm{R}$ & 5'-GGGCAGTGATCTCTTTCTGC-3' & \\
\hline \multirow{2}{*}{ B2M } & \multirow[t]{2}{*}{ NM_173893.3 } & A component of major histocompatibility class & $\mathrm{F}$ & 5'-AGACACCCACCAGAAGATGG-3' & \multirow[t]{2}{*}{64} \\
\hline & & I molecules; present in all nucleated cells & $\mathrm{R}$ & 5'-CGGCAGCTGTACTGATCCTT-3' & \\
\hline \multirow[t]{2}{*}{ GAPDH } & \multirow[t]{2}{*}{ NM_001034034.1 } & Oxidoreductase; has role in glycolysis and gluconeogenesis & $\mathrm{F}$ & 5'-GGGTCATCATCTCTGCACCT-3' & \multirow[t]{2}{*}{62} \\
\hline & & & $\mathrm{R}$ & 5'-GGTCATAAGTCCCTCCACGA-3' & \\
\hline \multirow[t]{2}{*}{$U X T$} & \multirow[t]{2}{*}{ NM_001037471.1 } & \multirow{2}{*}{ Receptor-induced transcriptional activation and tumorigenesis } & $\mathrm{F}$ & 5'-GAGCGACTCCAGGAAGCTAA-3' & \multirow{2}{*}{50} \\
\hline & & & $\mathrm{R}$ & 5'-CATGGAGTCCTTGGTGAGGT-3' & \\
\hline \multirow[t]{2}{*}{ MTG1 } & \multirow[t]{2}{*}{ NM_001025327.2 } & \multirow{2}{*}{ Mitochondrial translation } & $\mathrm{F}$ & 5'-CACTTGCTCGTCCTCAACAA-3' & \multirow[t]{2}{*}{50} \\
\hline & & & $\mathrm{R}$ & 5'-GGTGATAGCGG TAGCTGCTC-3' & \\
\hline \multirow[t]{2}{*}{$R P S 15 A$} & \multirow[t]{2}{*}{ NM_001037443.1 } & \multirow[t]{2}{*}{ Ribosomal protein that is a component of the $40 \mathrm{~S}$ subunit } & $\mathrm{F}$ & 5'-AATGTCCTGGCTGATGCTCT-3' & \multirow[t]{2}{*}{52} \\
\hline & & & $\mathrm{R}$ & 5'-GGGCTGATCACTCCACACTT-3' & \\
\hline \multirow[t]{2}{*}{ CSN2 } & \multirow[t]{2}{*}{ NM_181008 } & \multirow{2}{*}{ Common milk protein } & $\mathrm{F}$ & 5'-AAGCCAGAGCCTGACTCTCA-3' & \multirow[t]{2}{*}{52} \\
\hline & & & $\mathrm{R}$ & 5'-GGAACAGGCAGAACTTTGGA-3' & \\
\hline \multirow[t]{2}{*}{$R N 18 S 1$} & \multirow[t]{2}{*}{ Robinson et al., 2007} & \multirow[t]{2}{*}{ Ribosomal eukaryotic small subunit } & $\mathrm{F}$ & 5'-GTAACCCGTTGAACCCCATT-3' & \multirow[t]{2}{*}{60} \\
\hline & & & $\mathrm{R}$ & 5'-CCATCCAATCG GTAGTAGCG-3' & \\
\hline$U B C$ & Z18245 & Protein degradation and maturation of & $\mathrm{F}$ & 5'-AGATCCAGGATAAGGAAGGCAT-3' & 60 \\
\hline & & transcription factor nuclear factor- $\kappa \mathrm{B}$ & $\mathrm{R}$ & 5'-GCTCCACCTCCAGGGTGAT-3' & \\
\hline CAMP & NM_174831.2 & Antimicrobial peptide found in lysosomes in macrophages; & $\mathrm{F}$ & 5'-TTCGTGCTGTGGATCAGTTC-3' & 60 \\
\hline & & has role in mammalian innate immune defense system & $\mathrm{R}$ & 5'-ACTGTTTCACCAGCCCATTC-3' & \\
\hline$L T F$ & EU812318.1 & Iron-binding glycoprotein belonging to the & $\mathrm{F}$ & 5'-GATGAAGAAGCTGGGTGCTC-3' & 60 \\
\hline & & $\begin{array}{l}\text { transferrin family; bacteriostatic and bacteriocidal } \\
\text { and plays a role in innate defense }\end{array}$ & $\mathrm{R}$ & 5'-TGAAAGTTGCTGCCCCTTCTT-3' & \\
\hline
\end{tabular}

${ }^{1}$ PPP1R11 = protein phosphatase 1 regulatory subunit $11 ; A C T B=\beta$-actin; $B 2 M=\beta 2$ microglobulin; $U X T=$ ubiquitously expressed transcript; $M T G 1=$ mitrochondrial GTPase1 homolog; $R P S 15 A=40 \mathrm{~S}$ ribosomal protein S15a; $C S N 2=\beta$-casein; $R N 18 S 1=18 \mathrm{~S} \mathrm{rRNA} U \mathrm{UBC}=$ ubiquitin; $C A M P=$ cathelicidin; and $L T F=$ lactoferrin .

${ }^{2} \mathrm{~F}=$ forward; $\mathrm{R}=$ reverse. 


\section{ICG Stability Evaluation}

Simple statistical analysis (one-way ANOVA) was performed by taking the mRNA expression patterns of each ICG (data after transformation of $\mathrm{Cp}$ values using standard curve) in SigmaStat software (SyStat Inc., San Jose, CA) to observe the differences of raw expression of each selected ICG in early, mid, and late lactation stages. To assess the possible dilution effect of the genes during different stages of lactation, Pearson correlation coefficients of qPCR data after transformation using the standard curve of candidate ICG were calculated with $\beta$-casein (CSN2), lactoferrin $(L T F)$, and cathelicidin $(C A M P)$. All statistics were performed using SigmaStat software.

The data generated from qPCR for all the samples and genes under study were analyzed in geNorm and NormFinder. The raw qPCR data for each single gene after transformation of $\mathrm{Cp}$ values along with PCR efficiency from linear standard curve were analyzed using geNorm (Vandesompele et al., 2002). Briefly, in geNorm, stability (M, gene stability measure) refers to the constancy of expression ratio between 2 non-co-regulated genes among all tested samples. The more stable the expression ratio among 2 genes, the more likely that the genes are appropriate internal controls; that is, 2 identical genes should have an identical expression ratio in all samples regardless of experimental conditions. In geNorm, a lower $\mathrm{M}$ value indicates greater stability of the gene. The underlying principle and calculations are described by Vandesompele et al. (2002). Once the most stable pair of genes is selected, the normalization factor (NF) is calculated using geometrical mean of the relative expression. geNorm was also used to evaluate the optimum number of ICG used in expression studies on milk somatic cells by using pairwise variation $(\mathbf{V})$ analysis. To determine how many reference genes should be used, normalization factors $\left(\mathrm{NF}_{n}\right)$ based on the geometric mean of the expression level of the $n$ number of reference genes, were calculated by stepwise inclusion of an additional less-stable reference gene (Vandesompele et al., 2002). Briefly, the program calculates the pairwise variation $\mathrm{V}_{n} / \mathrm{V}_{n+1}$ between 2 sequential normalization factors $\mathrm{NF}_{n}$ and $\mathrm{NF}_{n+1}$. A large variation indicates that the added gene has a significant effect and thus should be included for the calculation of the normalization factor.

NormFinder is an algorithm for identifying the optimal normalization of gene among a set of candidates. The algorithm is rooted in a mathematical model of gene expression and uses a statistical framework to estimate not only the overall expression variation of candidate genes for normalization but also the variation between sample subgroup of the sample set. NormFinder pro- vides a stability value of each gene, a direct measure for the estimated expression variation, which enables us to evaluate the systematic error introduced when using the gene for normalization. The model and statistical framework underlying NormFinder were described by Andersen et al. (2004). For analysis, the data used in NormFinder were in the form of transformed $\mathrm{Cp}$ values for each gene, which were calculated from their respective standard curves.

\section{Evaluation and Validation of Experiment}

To validate the suitability of the selected ICG found to be stably expressed in the experiment, an evaluation of relative expression of CSN2, LTF, and CAMP was performed at 3 lactation stages (early, mid, and late), using a combination of 4 ICG (PPP1R11, $A C T B$, $U B C$, and $G A P D H$ ) and $G A P D H$ alone as reference genes, respectively. First-strand cDNA of all samples for all genes was diluted 5 times in nuclease-free water before performing qPCR. A master mix of $10 \mu \mathrm{L}$ for each sample was prepared as follows: $5 \mu \mathrm{L}$ of Roche SYBR Green master mix $(1 \times), 0.5 \mu \mathrm{L}$ of each of reverse and forward primers $(0.5 \mu M), 1 \mu \mathrm{L}$ of template cDNA, and $3 \mu \mathrm{L}$ of PCR-grade water. The real-time PCR program was $95^{\circ} \mathrm{C}$ for $5 \mathrm{~min}, 40$ cycles of $95^{\circ} \mathrm{C}$ for 10 $\mathrm{s}, 62^{\circ} \mathrm{C}$ for $10 \mathrm{~s}$, and $72^{\circ} \mathrm{C}$ for $15 \mathrm{~s}$. Melting curves (dissociation curves) for each gene were performed using the following temperature program: $95^{\circ} \mathrm{C}$ for $5 \mathrm{~s}, 65^{\circ} \mathrm{C}$ for $1 \mathrm{~min}$, and $97^{\circ} \mathrm{C}$ for continuous mode, as per the set default value of instrument. Calculation of relative expression for CSN2, $L T F$, and $C A M P$ was performed by following the equation described by Pfaffl (2001):

$$
\text { Ratio }=\frac{\left(\mathrm{E}_{\text {target }}\right) \Delta \mathrm{Cp} \text { target }(\text { control }- \text { sample })}{\left(\mathrm{E}_{\text {ref }}\right) \Delta \mathrm{Cp} \text { ref }(\text { control }- \text { sample })},
$$

where $E_{\text {target }}$ is the real-time PCR efficiency of the target gene transcript, and $\mathrm{E}_{\text {ref }}$ is the real-time PCR efficiency of the reference gene transcript. This equation shows a mathematical model of relative expression ratio in real-time PCR. The ratio of a target gene is expressed in a sample (mid and late lactation) versus a control (early lactation) compared with a reference gene. We found efficiencies of all tested genes (ICG and target genes) close to 2 (Supplemental file S1; available at http://www.journalofdairyscience.org/).

\section{RESULTS}

\section{Somatic Cell Analysis by Microscopic Count}

Milk samples (100-500 mL) from each animal yielded total somatic cell numbers in the range of 1.1 to $1.5 \times$ 
$10^{5}$ cells $/ \mathrm{mL}$ and the SCC were within physiological limits (Dang et al., 2008; De et al., 2011). The number of somatic cells did not vary substantially during different stages of lactation: early $=1.44 \pm 0.51 \times 10^{5}$, $\operatorname{mid}=1.11 \pm 0.22 \times 10^{5}$, and late $=1.36 \pm 0.82 \times 10^{5}$ cells $(P>0.05)$. The low SCC indicated the absence of mastitis. Cell viability, as assayed via trypan blue exclusion, was estimated to exceed $80 \%$.

\section{Primer Specificity and Transcript Expression}

Primers for the 9 ICG and 3 target genes of interest were highly specific as observed by the presence of a single band in agarose gel electrophoresis (Supplemental file S3) by the presence of a single peak in melting curve (dissociation curves) analysis after qPCR reaction (Supplemental file S4), and by sequence analysis of amplicons (Supplemental file S5). The Cp values are shown in Supplemental file S6 (all supplemental files available at http://www.journalofdairyscience.org/). Out of 9 ICG tested, 7 appeared to be expressed adequately with exception of 2 genes, UXT and MTG1, which showed either very low (above 40 cycles) or no expression in samples from the late lactation stage.

Simple statistical analysis (ANOVA; Supplemental file S7; available at http://www.journalofdairyscience. org/) of the tested ICG and the target genes (except casein) indicated that expression did not vary significantly during different stages of lactation $(P>0.05)$. Pearson correlation coefficient analysis to assess the possible dilution effect of candidate ICG with CSN2, $L T F$, and $C A M P$ showed no correlation (Supplemental file S7; available at http://www.journalofdairyscience. $\operatorname{org} /)$.

\section{Expression Stability of ICG by geNorm and NormFinder Software}

The average $M$ values for a pair of genes in each of the 3 stages of lactation were calculated to ascertain the stability in expression of genes among samples as lactation progressed from early to mid to late lactation, representing the full lactation length. We determined the variance of the $M$ value of these reference genes in 3 stages of lactation. The M values of the 7 ICG and the control genes expressed in 3 stages of lactation are shown in Figure 1a. The expression stabilities of the tested genes were observed to be different, with the $\mathrm{M}$ values ranging from 0.47 to 2.26 . The average $\mathrm{M}$ value of the pair PPP1R11 and ACTB was lowest, and this pair were identified as the most suitable reference genes with average $\mathrm{M}$ values of $<0.5$ (Figure 1a). The M value of $R N 18 S 1$ was the highest among ICG at 1.66
(Figure 1a) and was found to be the worst performing ICG. As expected (because expression of the CAMP gene was expected to be variable through lactation), the $\mathrm{M}$ value of $C A M P$ fluctuated most $(\mathrm{M}=2.26)$ among all the investigated genes, further strengthening the validity of the methods used for evaluation of ICG. Further, to determine how many ICG should be used to calculate the normalization factor, the pairwise variation (V) analysis proposed by Vandesompele et al. (2002) was performed. The result of $\mathrm{V}$ analysis is shown in Figure 1b; the best value of $\mathrm{V}$ was obtained using 4 ICG and was 0.155 .

The NormFinder algorithm was also used to calculate the expression stabilities of the 9 genes, in which higher expression stability is indicated by a lower stability value as an estimate of the combined intra- and inter group variation of the individual gene (Andersen et al., 2004). Overall, throughout the lactation, PPP1R11 was found to be the most stably expressed ICG, followed by $A C T B$ and $U B C$ (Figure 2). As expected, the stability index value of the candidate gene $C A M P$ fluctuated the most among the 10 investigated genes, with an overall stability index of 2.205. The results obtained from the methods used for evaluation of ICG showed similar results, and the observation of CSN2 as an unstable target gene further validated the present findings.

\section{Evaluation and Validation of Selected Candidate ICG}

Relative expression of CSN2, LTF, and CAMP was significantly different $(P<0.05)$ during late lactation when GAPDH alone and a combination of PPP1R11, $A C T B, U B C$, and $G A P D H$ were used as reference genes (Figure 3). The transcripts for CSN2, LTF, and CAMP were upregulated approximately 10-, 13-, and 14-fold when a combination of 4 ICG were used for normalization compared with $G A P D H$ alone. Further examination of the relative expression of the target genes during different stages of lactation indicated that CSN2 was upregulated both in mid and late lactation, $C A M P$ was upregulated in mid lactation and downregulated in late lactation, and $L T F$ was upregulated in mid lactation and downregulated in late lactation (Figure 3). This finding illustrates the use of combination of 4 ICG as a better choice than using a single ICG.

\section{DISCUSSION}

In this study, we focused on RT-qPCR data normalization in milk somatic cells of one of the major Indian zebu cattle (Sahiwal) to initiate transcriptional studies in this important cattle breed. The selection of ICG is important for normalization of quantitative gene ex- 
a)

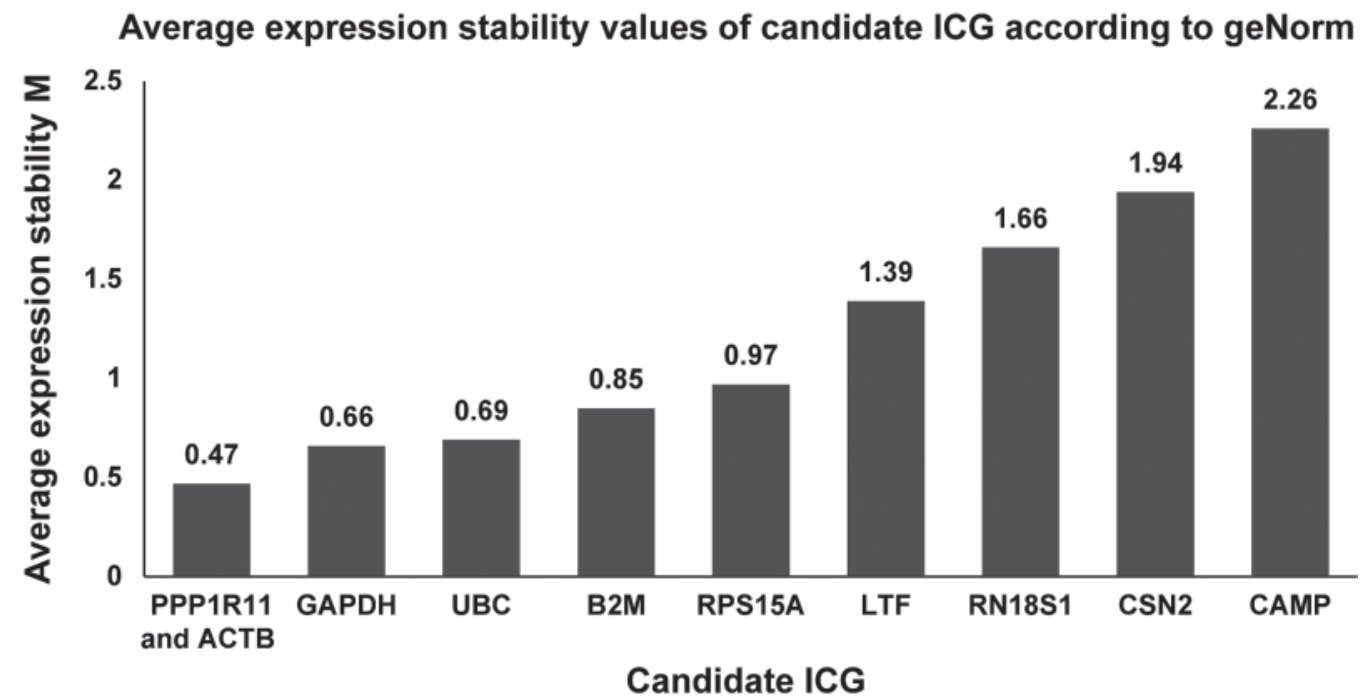

b)

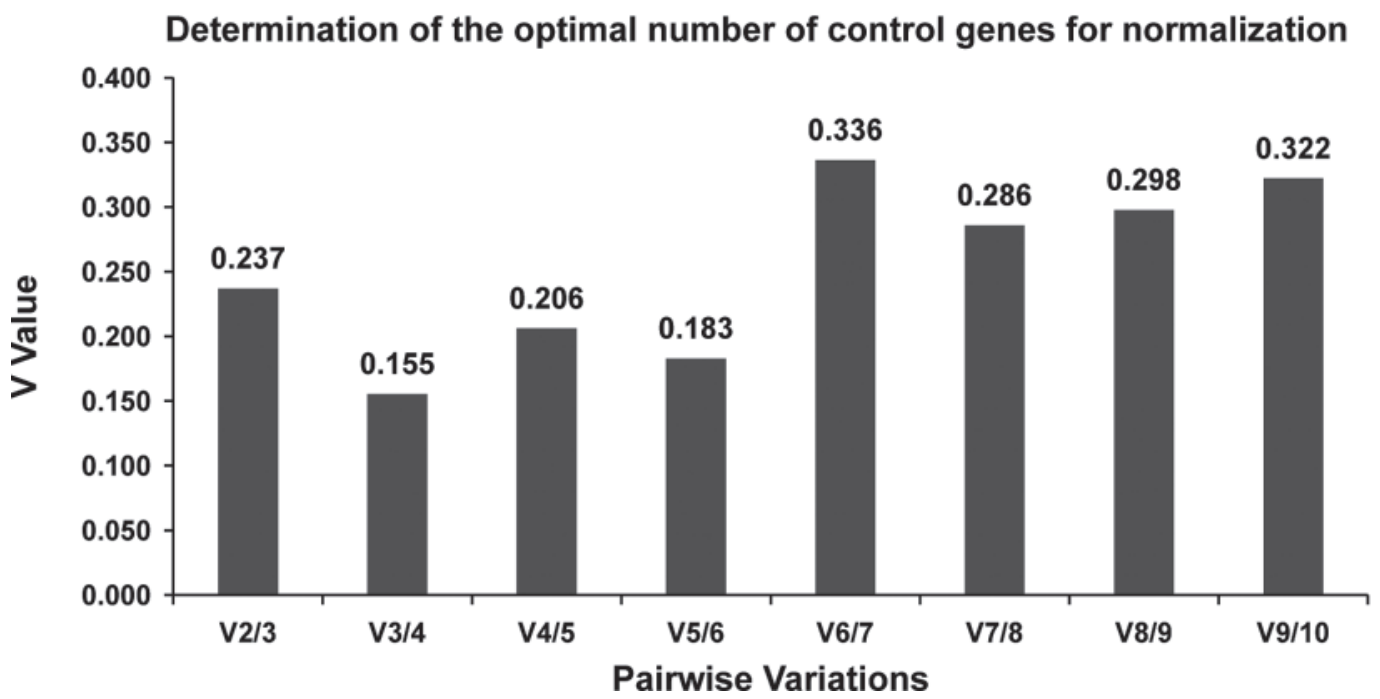

Figure 1. (a) Stability (M) of gene expression ratios of potential internal control genes (ICG) using GeNorm software. Values are reported as stepwise exclusion of the least-stable control genes. PPP1R11 and ACTB were the most stable ICG; (b) GeNorm pairwise analysis of optimal number of ICG for quantitative PCR normalization. The optimal number of ICG was determined by assessment of the pairwise variation V $\left(\mathrm{V}_{\mathrm{n} / \mathrm{n}+1}\right)$ between the normalization factors $\mathrm{NF}_{\mathrm{n}}$ and $\mathrm{NF}_{\mathrm{n}+1}$. Inclusion of 2 more genes $(G A P D H$ and $U B C)$ reduced the $\mathrm{V}$ value substantially.

pression results. Milk somatic cells have been used as a source material in gene expression studies for assessing mammary biology (Paape et al., 2002; Murrieta et al., 2006; Baumert et al., 2009).

The optimal reference gene should be constantly transcribed in all types of cells under any biological condition. However, it is difficult to find perfect reference genes that remain stably transcribed between samples taken at different time points (Nygard et al., 2007).
The expression of frequently used reference genes such as $G A P D H$ and $A C T B$ is affected by treatment in some cases (Glare et al., 2002; Radonić et al., 2004). The majority of expression studies by $\mathrm{qPCR}$ in the literature use a single internal control such as GAPDH, ACTB, or RN18S1 (de Jonge et al., 2007). A few research papers have been published using milk somatic cells for qPCR-based gene expression studies and almost all have used a single ICG. Others have used $U B C$ (Pfaffl 


\section{Stability of candidate ICG according to NormFinder}

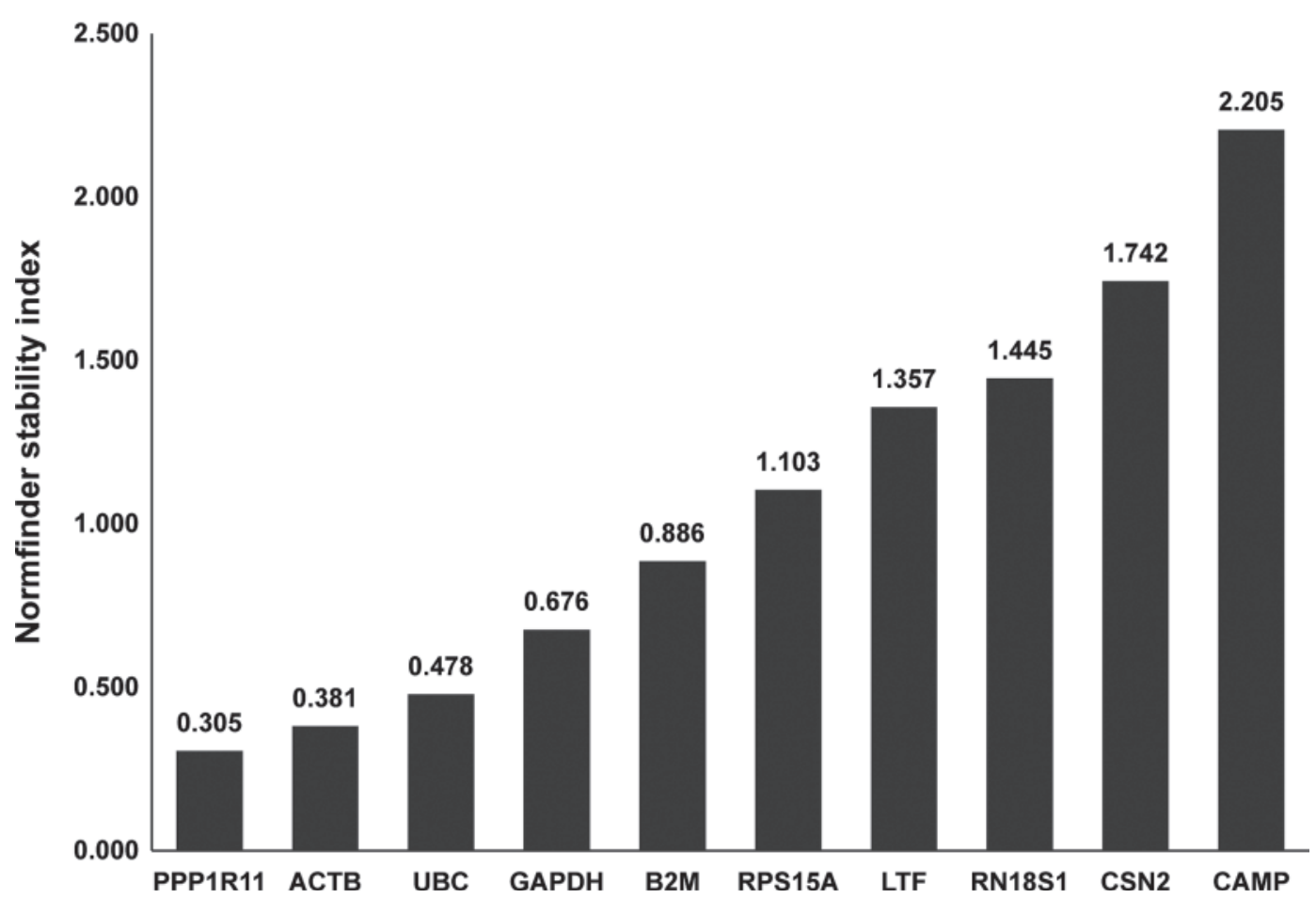

Figure 2. Stability index of genes according to NormFinder. A lower stability index value indicates greater stability of internal control genes (ICG).

et al., 2003; Lee et al., 2006), ACTB (Feng et al., 2007), and GAPDH (Boulanger et al., 2003) as ICG.

Presence of co-regulation among the tested ICG can introduce bias when genes are tested using geNorm (Piantoni et al., 2008). Some of the tested ICG such as $A C T B, B 2 M$, and GAPDH used in the present investigation have been reported to be co-regulated (Bionaz and Loor, 2007; Piantoni et al., 2008), which may limit the accuracy of geNorm results. In this study, gene network analysis indicating co-regulation or non-co-regulation was not carried out because all the selected genes were well known ICG reported in several other studies (Nygard et al., 2007; Pérez et al., 2008; Gubern et al., 2009). The instances in which co-regulation analysis has been attempted were for large sets of genes identified through microarray-based transcriptome analysis (Bionaz and Loor, 2007; Piantoni et al., 2008). Moreover, in the present investigation, we found good agreement between geNorm and Normfinder results regarding the ranking of the 4 most stable genes (PPP1R11, ACTB, $U B C$, and $G A P D H)$. Both methods of analysis identified PPP1R11 as the most stable reference gene in our experimental design. Because we found no discrepancy between the 2 algorithms used, we assumed a lack of co-regulation effect among the 4 most stable genes.
Additionally, Normfinder results are generally thought to be unaffected by the co-regulation phenomenon. Further, we observed PPP1R11 to be one of the most stable ICG, which was not co-regulated with any of the tested genes; thus, the geNorm results were sufficiently reliable for correct interpretation.

To assess a possible dilution effect of tested ICG through lactation, we performed Pearson correlation coefficient analysis of raw $\mathrm{qPCR}$ data (after transformation using the standard curve) of all ICG and target genes. However, we did not observe an inverse correlation of any ICG with any of the target genes in milk somatic cells through lactation, which indicated that a dilution effect due to overexpression of other genes was absent in our study (Supplemental file S7; available at http://www.journalofdairyscience.org/). Bionaz and Loor (2007) observed an apparent dilution effect of ICG in bovine mammary tissue from pregnancy to early-mid lactation.

The most widely used method to evaluate stable expression of ICG is the statistical analysis of raw gene expression data to ensure that a group effect (or treatment effect) among samples is not associated with the variation in the expression of selected ICG. We did not observe any significant difference in the 

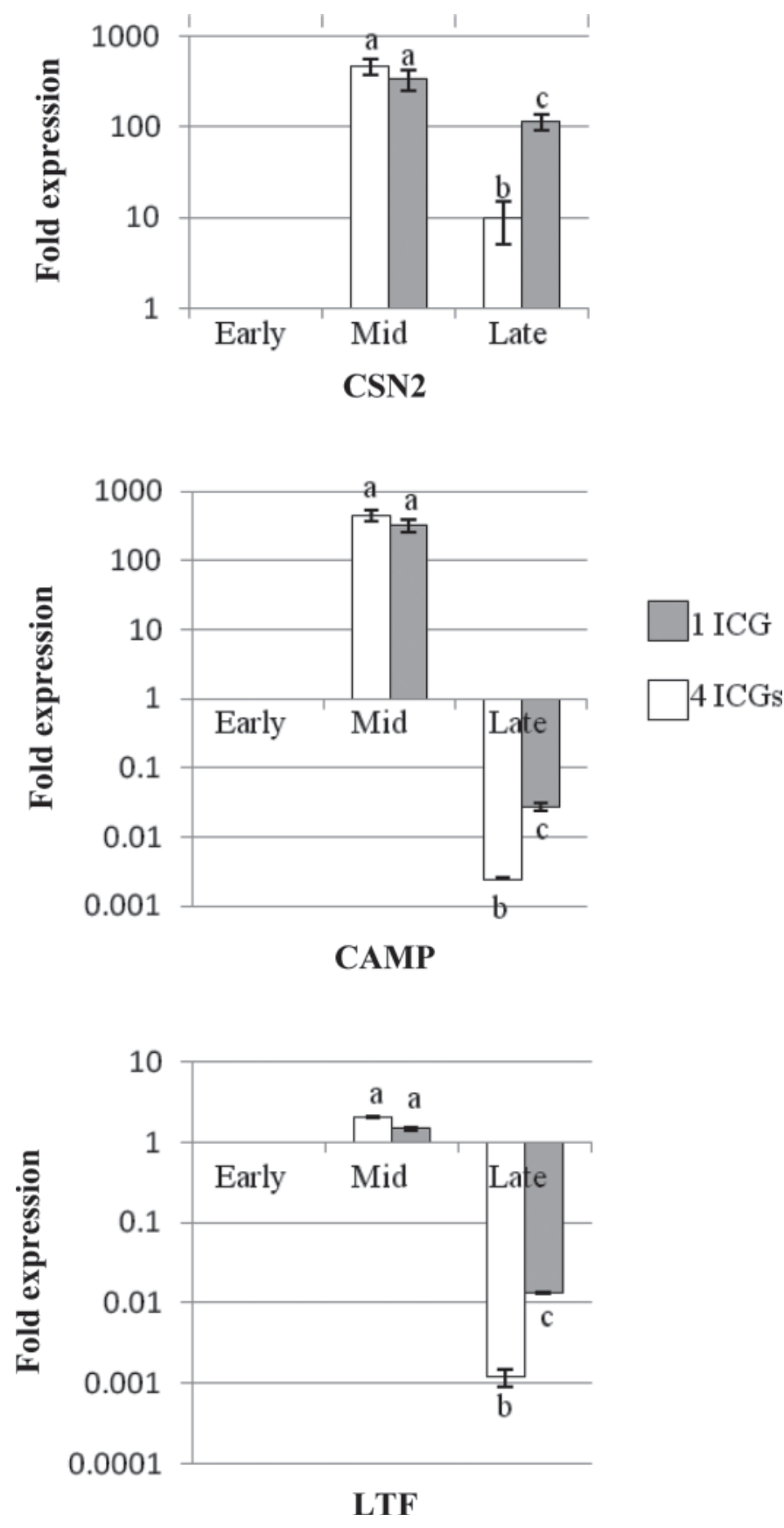

Figure 3. Relative expression of target genes (i.e., CSN2, CAMP, and $L T F$ ) during mid and late lactation compared with early lactation, taking $G A P D H$ alone and the combination of 4 internal control genes (ICG; PPP1R11, $A C T B, U B C$, and $G A P D H$ ) as reference genes, respectively. Error bars represent SEM within the group. Significant difference $(P<0.05)$ between 1 ICG and 4 ICG was observed during late stage.

expression of tested ICG throughout lactation (at $P>$ 0.05 ). This method, however, is not appropriate to select accurately ICG. In fact, among other issues, simple statistical analysis of the number of transcripts of the ICG is unable to account for the dilution effect (Bionaz and Loor, 2007). Therefore, geNorm and NormFinder software were used for determination of expression stability. To our knowledge, this is the first detailed study of the stability of few selected reference genes in milk somatic cells. Both geNorm and NormFinder showed similar results, with the pair of PPP1R11 and $A C T B$ being the most stable. However, geNorm and NormFinder differed concerning a third stable ICG. In geNorm, the $\mathrm{M}$ values for $G A P D H$ and $U B C$ were similar (Figure 1a), whereas, in NormFinder, $U B C$ was the third most stable ICG (Figure 2). Based upon the observations from geNorm and NormFinder, the combination of PPP1R11, ACTB, UBC, and GAPDH seem to fulfill the criteria for their use as ICG. The $R N 18 S 1$ gene was the worst scoring ICG tested and was thus deemed unsuitable for qPCR normalization in our experiment (Figures 1a, 1b, 2). This is an important observation given the fact that in some of the gene expression studies in milk somatic cells and mammary tissue, $R N 18 S 1$ was used as ICG (Murrieta et al., 2006; Sørensen et al., 2006); RN18S1 has general disadvantages when used as reference gene (Vandesompele et al., 2002). For instance, rRNA genes are highly abundant compared with the targeted mRNA transcripts, which makes it difficult to accurately subtract the baseline values in RT-qPCR analysis (Vandesompele et al., 2002). The $U B C$ gene has frequently been used as a single ICG in many experiments (Cheng et al., 2011). In the present investigation, identification of $P P P 1 R 11$ along with $A C T B$ as the pair of most stable reference genes ahead of $U B C$ is a new finding. Piantoni et al. (2008) suggested that the geometric mean of 3 reference genes; namely, PPP1R11, RPS15A, and MTG1, was the most stable in prepubertal bovine mammary tissue from calves fed different milk replacers. Bionaz and Loor (2007) suggested the geometric average of 3 genes, UXT, RPS9, and RPS15, as internal control for longitudinal mammary gene expression profiling. The choice of $U X T$ and MTG1 as most stable ICG (along with RPS9 and RPS15) may not be suitable for milk somatic cells, because expression of UXT and MTG1 was very low.

To determine how many ICG should be used, an NF based on the geometric mean of the best performing ICG was calculated by stepwise inclusion of an additional less-stable reference gene. Results using geNorm and NormFinder indicated that PPP1R11, ACTB, $U B C$, and $G A P D H$ were the most stable ICG (Figure 1a). The $\mathrm{V}$ value obtained after inclusion of the third gene (V2/V3) was 0.23. Vandesompele et al. (2002) proposed 0.15 as a cut off value for the pairwise varia- 
tion $(\mathrm{Vn} / \mathrm{Vn}+1)$. After inclusion of the fourth ICG $(U B C)$, a substantial reduction in the $\mathrm{V}$ value $(0.15)$ was observed in geNorm (Figure 1b). This suggested the need for inclusion of a fourth gene as ICG. Therefore, it would be ideal to include 4 genes (PPP1R11, ACTB, $U B C$, and $G A P D H)$ as ICG for normalization of qPCR data in milk somatic cells, mainly because the $\mathrm{V}$ value came close to the generally accepted limit of 0.15 after addition of the fourth gene. Hence, the average geometric mean of the 4 best ICG (PPP1R11, ACTB, UBC, and $G A P D H)$ found suitable in the present investigation can be used as internal control for normalization of $\mathrm{qPCR}$ data in milk somatic cells. To validate the usefulness of selecting a combination of these 4 ICG against using a single ICG $(G A P D H)$, we performed the relative quantification of the target genes during mid and late compared with early lactation. We observed a significant difference $(P<0.05)$ in the expression of all target genes during the late lactation stage (Figure 3 ). Moreover, the expression level of the target genes was comparatively lower when a combination of 4 ICG was used compared with 1 ICG. A similar trend of expression of target genes substantiates the choice of 4 ICG compared with 1 ICG for normalization. Therefore, the use of a combination of 4 ICG is a better choice than using a single ICG for normalization of $\mathrm{qPCR}$ data in milk somatic cell during lactation.

\section{CONCLUSIONS}

In the present study, we investigated reliable ICG for normalization of RT-qPCR data obtained from milk somatic cells of lactating cows. Expression stability varied appreciably among tested ICG. The geometric average of PPP1R11, ACTB, UBC, and GAPDH could be used as ICG for gene expression assays in milk somatic cells during lactation.

\section{ACKNOWLEDGMENTS}

We are grateful for the financial support from $\mathrm{Na}$ tional Agriculture Innovation Project (NAIP), Indian Council of Agricultural Research, India, to carry out this research work.

\section{REFERENCES}

Andersen, C. L., J. L. Jensen, and T. F. Ørntoft. 2004. Normalization of real-time quantitative reverse transcription-PCR data: A model based variance estimation approach to identify genes suited for normalization, applied to bladder and colon cancer data sets. Cancer Res. 64:5245-5250.

Baumert, A., R. M. Bruckmaier, and O. Wellnitz. 2009. Cell population, viability, and some key immunomodulatory molecules in different milk somatic cell samples in dairy cows. J. Dairy Res. $76: 356-364$.
Bionaz, M., and J. J. Loor. 2007. Identification of reference genes for quantitative real-time PCR in the bovine mammary gland during the lactation cycle. Physiol. Genomics 29:312-319.

Boulanger, D., F. Bureau, D. Melotte, J. Mainil, and P. Lekeux. 2003. Increased nuclear factor $\kappa \mathrm{B}$ activity in milk cells of mastitis-affected cows. J. Dairy Sci. 86:1259-1267.

Boutinaud, M., M. H. Ben Chedly, E. Delamaire, and J. GuinardFlament. 2008. Milking and feed restriction regulate transcripts of mammary epithelial cells purified from milk. J. Dairy Sci. 91:988-998.

Boutinaud, M., and H. Jammes. 2002. Potential uses of milk epithelial cells: A review. Reprod. Nutr. Dev. 42:133-147.

Boutinaud, M., H. Rulquin, D. H. Keisler, J. Djiane, and H. Jammes. 2002. Use of somatic cells from goat milk for dynamic studies of gene expression in the mammary gland. J. Anim. Sci. 80:12581269.

Cheng, W.-C., C. W. Chang, C. R. Chen, M. L. Tsai, W. Y. Shu, C. Y. Li, and I. C. Hsu. 2011. Identification of reference genes across physiological states for qRT-PCR through microarray meta analysis. PLoS ONE 6:e17347.

Cikos, S., A. Bukovska, and J. Koppel. 2007. Relative quantification of mRNA: Comparison of methods currently used for real-time PCR data analysis. BMC Mol. Biol. 8:113.

Dang, A. K., S. Kapila, C. Singh, and J. P. Sehgal. 2008. Milk differential cell counts and compositional changes in cows during different physiological stages. Milchwissenschaft 63:239-242.

De, K., J. Mukherjee, A. K. Dang, and S. Prasad. 2011. Effect of different physiological stages and managemental practices on milk somatic cell counts of Murrah buffaloes. Buff. Bull. 30: 72-74,99.

de Jonge, H. J. M., R. S. N. Fehrmann, E. S. J. M. de Bont, R. M. W. Hofstra, F. Gerbens, W. A. Kamps, E. G. E. de Vries, A. G. J. van der Zee, G. J. te Meerman, and A. ter Elst. 2007. Evidence based selection of housekeeping genes. PLoS ONE 2:e898.

Dheda, K., J. F. Huggett, J. S. Chang, L. U. Kim, S. A. Bustin, M. A. Johnson, G. A. Rook, and A. Zumla. 2005. The implications of using an inappropriate reference gene for real-time reverse transcription PCR data normalization. Anal. Biochem. 344:141-143.

Feng, Y., D. Manka, K. U. Wagner, and S. A. Khan. 2007. Estrogen receptor $\alpha$ expression in the mammary epithelium is required for ductal and alveolar morphogenesis in mice. Proc. Natl. Acad. Sci. USA 104:14718-14723.

Glare, E. M., M. Divjak, M. J. Bailey, and E. H. Walters. 2002. $\beta$-Actin and GAPDH housekeeping gene expression in asthmatic airways is variable and not suitable for normalising mRNA levels. Thorax 57:765-770.

Gubern, C., O. Hurtado, R. Rodríguez, J. R. Morales, V. G. Romera, M. A. Moro, I. Lizasoain, J. Serena, and J. Mallolas. 2009. Validation of housekeeping genes for quantitative real-time PCR in in vivo and in vitro models of cerebral ischaemia. BMC Mol. Biol. 10:57-62.

Jung, M., J. Spethmann, and A. Kalbe. 2002. Housekeeping gene sets facilitate the search for a suitable reference gene for relative quantification. Biochemica (Indianapolis) 4:9-11.

Lee, J., J. H. Mo, K. Katakura, I. Alkalay, A. N. Rucker, Y. T. Liu, H. K. Lee, C. Shen, G. Cojocaru, S. Shenouda, M. Kagnoff, L. Eckmann, Y. B. Neriah, and E. Raz. 2006. Maintenance of colonic homeostasis by distinctive apical TLR9 signalling in intestinal epithelial cells. Nat. Cell Biol. 8:1327-1336.

Medrano, J. F., G. Rincon, and A. Islas-trejoi. 2010. Comparative analysis of bovine milk and mammary gland transcriptome using RNA-seq. Page 852 in 9th World Congr. Genet. Appl. Livest. Prod., Leipzig, Germany. German Society of Animal Science, Leipzig, Germany.

Murrieta, C. M., B. W. Hess, E. J. Scholljegerdes, T. E. Engle, K. L. Hossner, G. E. Moss, and D. C. Rule. 2006. Evaluation of milk somatic cells as a source of mRNA for study of lipogenesis in the mammary gland of lactating beef cows supplemented with dietary high-linoleate safflower seeds. J. Anim. Sci. 84:2399-2405.

Nygard, A. B., C. B. Jørgensen, S. Cirera, and M. Fredholm. 2007. Selection of reference genes for gene expression studies in pig tissues using SYBR Green qPCR. BMC Mol. Biol. 8:67. 
Paape, M., J. Mehrzad, X. Zhao, J. Detilleux, and C. Burvenich. 2002. Defense of the bovine mammary gland by polymorphonuclear neutrophil leukocytes. J. Mammary Gland Biol. Neoplasia 7:109-121.

Pérez, R., Y. T. Isabel, and S. Dunner. 2008. Evaluation of suitable reference genes for gene expression studies in bovine muscular tissue. BMC Mol. Biol. 9:79.

Pfaffl, M. W. 2001. A new mathematical model for relative quantification in real-time RT-PCR. Nucleic Acids Res. 29:e45.

Pfaffl, M. W. 2004. Quantification strategies in real-time PCR. Pages 87-120 in A-Z of Quantitative PCR. S. A. Bustin, ed. IUL Biotechnology Series, La Jolla, CA.

Pfaffl, M. W., S. L. Wittmann, H. H. D. Meyer, and R. M. Bruckmaier. 2003. Gene expression of immunologically important factors in blood cells, milk cells, and mammary tissue of cows. J. Dairy Sci. 86:538-545.

Piantoni, P., M. Bionaz, D. E. Graugnard, K. M. Daniels, R. M. Akers, and J. J. Loor. 2008. Gene expression ratio stability evaluation in prepubertal bovine mammary tissue from calves fed different milk replacers reveals novel internal control for quantitative polymerase chain reaction. J. Nutr. 138:1158-1164.

Radonić, A., S. Thulke, I. M. Mackay, O. Landt, W. Siegert, and A. Nitsche. 2004. Guideline to reference gene selection for quantitative real-time PCR. Biochem. Biophys. Res. Commun. 313:856-862.

Robinson, T. L., I. A. Sutherland, and J. Sutherland. 2007. Validation of candidate bovine reference genes for use with real-time PCR Vet. Immunol. Immunopathol. 115:160-165.

Rozen, S., and H. J. Skaletsky. 2000. Primer3 on the WWW for general users and for biologist programmers. Pages 365-386 in Bioinformatics Methods and Protocols: Methods in Molecular Biology. S. Krawetz, and S. Misener, ed. Humana Press, Totowa, NJ.

Schmittgen, T. D., B. A. Zakrajsek, A. G. Mills, V. Gorn, M. J. Singer, and M. W. Reed. 2000. Quantitative reverse transcription- polymerase chain reaction to study mRNA decay: Comparison of endpoint and real-time methods. Anal. Biochem. 285:194-204.

Silver, N., S. Best, J. Jiang, and S. L. Thein. 2006. Selection of housekeeping genes for gene expression studies in human reticulocytes using real-time PCR. BMC Mol. Biol. 7:33.

Sørensen, O. E., D. R. Thapa, K. M. Roupe, E. V. Valore, U. Sjöbring, A. A. Roberts, A. Schmidtchen, and T. Ganz. 2006. Injury-induced innate immune response in human skin mediated by transactivation of the epidermal growth factor receptor. J. Clin. Invest. 116:1878-1885.

Tomasinsig, L., G. D. Conti, B. Skerlava, R. Piccinini, M. Mazzilli, F. D'Este, A. Tossi, and M. Zanetti. 2010. Broad-spectrum activity against bacterial mastitis pathogens and activation of mammary epithelial cells support a protective role of neutrophil cathelicidins in bovine mastitis. Infect. Immun. 78:1781-1788.

Tricarico, C., P. Pinzani, S. Bianchi, M. Paglierani, V. Distante, M. Pazzagli, S. A. Busin, and C. Orlando. 2002. Quantitative realtime reverse transcription polymerase chain reaction: Normalisation to rRNA or single housekeeping genes is inappropriate for human tissue biopsies. Anal. Biochem. 309:293-300.

Vandesompele, J., K. D. Preter, F. Pattyn, B. Poppe, N. Van Roy, A. D. Paepe, and F. Speleman. 2002. Accurate normalization of realtime quantitative RT-PCR data by geometric averaging of multiple internal control genes. Genome Biol. 3:RESEARCH0034.

Yüzbaşioğlu, A., İ. Onbaşılar, Ç. Kocaefe, and M. Özgüç. 2010. Assessment of housekeeping genes for use in normalization of real time PCR in skeletal muscle with chronic degenerative changes. Exp. Mol. Pathol. 88:326-329.

Zanetti, M. 2005. The role of cathelicidins in the innate host defenses of mammals. Curr. Issues Mol. Biol. 7:179-196. 